\title{
The Blessings of Blindness: Divine Illumination as Spiritual Health
}

\author{
Peter Steiger \\ Chaminade University of Honolulu, USA \\ psteiger@chaminade.edu
}

\section{Summary}

Among early Christian writers, Didymus of Alexandria occupies an unusual position being a theologian who garnered renown while enduring a significant physical disability, since he became blind in early childhood. Scholars of Didymus have frequently bemoaned the lack of biographical information concerning this famous teacher, and some suggest that Didymus never expresses regret for losing his physical eyesight in his own writing, arguing that he considered spiritual insight more valuable. Most recent monographs on Didymus have been content to cite traditions about Didymus' blindness, but few have sought to track the emergence of the few traditions about him and how these sources might relate to each other and have conflicting theological agendas. This paper seeks to address these lacunae by closely examining references to Didymus from his own contemporaries, all of whom personally met him, in order to make some suggestions of how this might open some new avenues for better understanding attitudes toward physical disability in early Christianity and particularly Didymus as a blind Christian theologian.

\section{Keywords}

Didymus the Blind - divine illumination - Jerome - Rufinus - Evagrius - Palladius

Modern assessments of Didymus of Alexandria have almost exclusively focused on his career as a teacher of late antiquity whose writings reveal him to be an exceptional exegete of scripture and insightful theologian, but there has been nearly no significant effort to examine his unique place as a blind early Christian who achieved great renown for his erudition in his own lifetime. 
Most recent monographs on Didymus have been content to cite traditions about Didymus' blindness and lament the lack of biographical data about him, but few have sought to track the emergence of the few traditions about him and how these sources might relate to each other and have conflicting theological agendas. This paper seeks to address these lacunae by closely examining references to Didymus from his own contemporaries, all of whom personally met him, in order to make some suggestions of how this might open some new avenues for better understanding attitudes toward physical disability in early Christianity and particularly Didymus as a blind Christian theologian.

Among the ancient sources of information on Didymus, four deserve particular attention because they had personal acquaintance with him; they are: Jerome, Rufinus, Evagrius and Palladius. ${ }^{1}$ The most significant late antique sources are from Jerome and Rufinus, who say a lot about Didymus during their bitter controversy about Origen's theology, though the narratives from Evagrius and Palladius add significant details. We will begin with Jerome's descriptions of Didymus because his notices are the first to appear, and the first to specifically reference the occasion of Didymus' blindness. ${ }^{2}$ Although contemporary scholars universally designate Didymus as "the Blind," this was not the practice in antiquity. Earliest references to Didymus tend to emphasize his residence in Alexandria and acknowledge his physical disability, albeit implicitly, indicating that his renown in the late fourth century was in part due to the fact that his aptitudes were not hindered by his physical disability.

1 Though Gregory of Nazianzus and his brother did visit Alexandria in circa 348-349 c.e., and his theology is similar to that of Didymus, there are no traditions of the two meeting in the extant material from either author. See J.A. McGuckin, St. Gregory of Nazianzus:An Intellectual Biography, Crestwood NY, 2001, pp. 48-49.

2 The first scholar to give thorough attention to the biographical data is Richard Layton, whose excellent treatment gives priority to the account of Rufinus. It is the longest notice and Rufinus may have had the most personal contact with Didymus, but these facts do not mean that his account is the most historically reliable. Indeed, it is likely that the biographical notices of Evagrius, Rufinus and Palladius are all influenced by Jerome, since they are in some ways derivative of information that Jerome provided initially and are reacting to portraits of Didymus first drawn by Jerome. This paper argues that, although historically problematic by modern standards, Jerome's portrait is more reliable because it is more nuanced, even conflicted, reflecting Jerome's complex relationship to Didymus, whereas the accounts of Rufinus and Palladius are uniformly laudatory, and that of Evagrius is too brief to thoroughly assess in historical terms. For more, see R.A. Layton, Didymus the Blind and His Circle in Late-Antique Alexandria, Urbana and Chicago, 2004, pp. 13-26, and G.D. Bayliss, The Vision of Didymus the Blind A Fourth Century Virtue-Origenism, Oxford, 2016, pp. 8-29. 


\section{Didymus in the Writings of Jerome}

The earliest extant written references to Didymus derive from Jerome, beginning with the preface of Jerome's Latin translation of Didymus' theological treatise On the Holy Spirit. ${ }^{3}$ Addressed to Paulinian, Jerome's younger brother and fellow monk, the translation was published circa 386 in reaction to a work of the same name published by Ambrose of Milan in 381 c.e. ${ }^{4}$ It must be assumed that Paulinian was already aware of Didymus' physical blindness, since he could not have grasped the significance of Jerome's words about the author of $D S S$ without knowing this biographical detail about Didymus. ${ }^{5}$ In the preface, Jerome does not explicitly call Didymus 'the blind,' but instead praises Didymus implicitly while simultaneously critiquing Ambrose, whom he accuses of plagiarizing from Didymus but failing to render good Latin from the Alexandrian's good Greek. Jerome concludes his preface with several biblical allusions that implicitly highlight Didymus' spiritual insight:

But my dear Didymus, who has the eye of the bride in the Song of Songs and those lights (lumina = lamps) which Jesus commanded be lifted up to the white harvests, gazed even higher and restored for us the ancient custom of calling a prophet a seer. Whoever reads this will recognize how the Latins have robbed him and will scorn the trickling stream once he begins to drink from the gushing spring. However unskilled in speaking he may be, he is not lacking in knowledge, for his very style shows that he is an apostolic man as much as by the authority of his thoughts as by simplicity of his words. ${ }^{6}$

While it is immediately obvious that Jerome uses several biblical allusions to praise Didymus for his keen theological understanding, closer examination of the biblical verses reveals that Jerome is speaking volumes about Didymus. While at Rome from 382-384 c.e., immediately prior to his visit to Alexandria, Jerome had served as secretary for Pope Damasus, during which time he made a translation of Origen's homilies on the Song of Songs, so his reference to the

3 Hereafter DSS - De Spiritu Sancto.

4 Didymus' $D S s$ has been dated to $360-365$ c.e. See the Introduction to DSS in the Popular Patristics Series, volume 43, Works on the Spirit: Athanasius and Didymus the Blind, ed. by M. DelCogliano, A. Radde-Gallwitz and L. Ayers, Yonkers, NY, 2011, pp. 37-48.

5 Although there is no evidence that Paulinian personally met Didymus, it is possible that Paulinian heard about Didymus' physical blindness from Jerome, or maybe he accompanied Jerome during his travels to Alexandria in the previous year.

6 Dss, ed. DelCogliano, p. 141. 
bride of the Song of Songs makes perfect sense. ${ }^{7}$ Unlike the text of the preface to $D S s$, we note that the biblical text of the Song of Songs never refers to the eye of the bride in the singular, only to her eyes plural; the Latin word Jerome uses, oculum, can be translated as eye, but also as vision, sight, or the mind's eye. ${ }^{8}$ Elsewhere in his commentary on the Song of Songs, Origen had suggested of the bride's eyes that the person who has these is a person with eyes like doves because

now she (the soul) does not understand the divine Scriptures after the letter but after the Spirit, and in them (the Scriptures) beholds spiritual mysteries; for the dove is a token of the Holy Spirit. Hence to have the eyes of the dove means to understand the Law and Prophets with a spiritual sensibility. ${ }^{9}$

Origen links verses on the eyes of the bride in Song of Songs to other biblical texts, such as Psalm 68:13, saying the soul with the wings of the dove is able to soar in the understanding of spiritual mysteries. Following Origen, Jerome has intentionally altered the plural to the singular in order to emphasize Didymus' spiritual comprehension in his treatise On the Holy Spirit.

Next, Jerome's preface says Didymus has the "lamps (Latin = lumina) which Jesus commanded to be lifted higher to the white harvests." ${ }^{10}$ Several biblical texts are alluded to again and immediately there is another shift from the singular eye to the plural lamps; Jerome is drawing together three texts: Matthew

$7 \quad$ A. Cain, The Letters of Jerome: Asceticism, Biblical Exegesis and the Construction of Christian Authority in Late Antiquity, Oxford, 2009, pp. 49-50. Cain's work on Jerome provides ample evidence that caution is necessary in assessing the historical reliability of much of the Hieronymian epistolary corpus, since Jerome frequently writes with barely veiled propagandizing purposes.

8 See Song of Songs 1:15, 4:1, 4:9, 6:5. Biblical translations in English are taken from the New American Bible (1991 edition). Layton says that Jerome makes a similar reference to the eye of the bride in his Letter 76 to Abigaus, a blind presbyter in Spain, where he again refers to the ants, flies and creeping things. Layton, Didymus the Blind, 2004, p. 22; here Layton is following the translation of the Septuagint for Song of Songs 4:9 that refers to "one of the (bride's) eyes" whereas modern translations follow the Masoretic text, rendering 4:9 as "a glance of your eyes."

9 The English translation of Origen's commentary on the Song of Songs is from The Song of Songs Interpreted by Early Christian and Medieval Commentators, R.A. Norris, ed. (The Church's Bible, gen. ed., R. Wilken), Grand Rapids and Cambridge, 2003, pp. 81-82.

As was the case with oculum, the Latin word lumina can be translated as lamps or even light of the eyes; this slightly different translation would then draw together the allusion to the eye of the Bridegroom with Jesus' parable of the wise virgins who are prepared to meet the Bridegroom. 
5:14, Matthew 6:22-23 and Matthew 25:1-13. ${ }^{11}$ By using this intertextual allusion, Jerome is describing Didymus with a method that encourages the reader to look beyond the literal meaning to find spiritual significance through recollection of other biblical texts, a technique Didymus himself practiced and advocated. The reference to 'lifting up' alludes to verses like Psalms 34:5, 121:1 and 123:1, Isaiah 40:26, Daniel 14:31, John 11:41 and 17:1, and Acts 7:55, all of which refer to raising the spiritual gaze of those filled with the Holy Spirit who use their vision to behold the glory of God known by the mind. The 'white harvests' and 'stream that becomes a gushing spring' are references to Jesus' discussion with the Samaritan woman in John 4, and the fountain of living water is also frequently tied to wisdom and understanding, the gifts of the Holy Spirit. ${ }^{2}$

Jerome then claims that Didymus' spiritual insight has revived the ancient practice found in 1 Samuel 9:9 where one who sought out a prophet asked for a seer. Likewise, Didymus lives up to his apostolic namesake, Thomas Didymus, who did not initially see the risen Christ, but proclaimed Jesus as Lord and God when he was invited to touch Jesus. ${ }^{13}$ According to Jerome, Didymus thus becomes one who fulfills the biblical prophecies of Psalm 146:8 "the Lord gives sight to the blind," and Jesus' words to Thomas Didymus in John 20:29 "Blessed are those who have not seen, yet believe." Additionally, Jerome considers Didymus to possess the apostolic qualities of Paul, whose plain language and untrained speech were coupled with spiritual knowledge in order that the wisdom of God could shine through him in the power of the Holy Spirit. ${ }^{14}$ In his brief preface to Dss, Jerome has revealed the spiritual authority of the one whose work he is translating. By examining his various biblical allusions, it becomes obvious that Jerome wants to contrast Didymus'

$11 \quad$ Matthew 5:14 'You are the light of the world. A city set on a mountain cannot be hidden. Nor do they light a lamp and then put it under a bushel basket; it is set on a lamp stand, where it gives light to all in the house. Just so, your light must shine before all.' Matthew 6:22-23 'The lamp of the body is the eye. If your eye is sound, your whole body will be filled with light; but if your eye is bad, your whole body will be in darkness. And if the light in you is darkness, how great will the darkness be.' Matthew 25:1-13 is the parable of the ten virgins, which begins 'The kingdom of heaven will be like ten virgins who took their lamps and went out to meet the Bridegroom.' The remainder of the passage speaks about the wise virgins who were prepared for the delay of the Bridegroom and can thus behold him with lamps lit when he welcomes them into the wedding feast. Jerome has thus indicated that Didymus is a light to others, especially those in the Church, that his enlightenment is reflected in his own state of life since he leads a holy life even though he is disabled, and his wisdom and holiness prepared him to behold the Bridegroom. Proverbs 13:14, Ecclesiastes 1:5, Isaiah 11:2-9.

13 John 20:24-29.

14 1st Corinthians 2:4, 2nd Corinthians 11:6. 
lack of physical sight with his immense spiritual and intellectual capability. And beyond merely referencing how Didymus is emblematic of a few scriptural verses, he actually imitates the practice of Didymus by heaping up multiple intertextual scripture references so as to create an interlocking, mutually explanatory series of verses, thereby justifying Jerome's reference to his Alexandrian master as 'my Didymus.' Thus, Jerome suggests that Didymus is worthy of emulation and admiration, regardless of his physical condition. ${ }^{15}$

The next reference to Didymus in Jerome's writings is entry 109 in On the Lives of Illustrious Men composed in 392, immediately prior to the first rumblings of controversy about Origen prompted by Epiphanius' visit to the Holy Land in 393-394. ${ }^{16}$ The tone of Vir. Ill. 109 is markedly different from the preface to $D s s$. The language is plain with no biblical allusions, in large part because a central purpose of Vir. Ill. was to generate a list cataloguing the contents of his library, though it is also clear that Jerome presents himself as the culmination and successor of the illustrious men by listing himself and his writings last. ${ }^{17}$ It states that Didymus is from Alexandria and became blind

15 Jerome's obvious admiration of Didymus became one of the key problems as he became embroiled in the debate with Rufinus over the theology of Origen. Rufinus rightly asked how Jerome could so clearly admire someone whom he would later accuse of holding heretical views. And it is in the heat of conflict over Origen that Jerome attempts to distance himself from Didymus whom he had previously praised. For the best discussion of the Origenist debate, see Elizabeth A. Clark, The Origenist Controversy: The Cultural Construction of an Early Christian Debate, Princeton, 1992. Clark's work examines the intricacies of this conflict, giving ample attention to the role of Jerome, Rufinus, Evagrius and Palladius, as well as their web of social, ecclesiastical and theological alliances, but gives very little attention to the role of Didymus, who was in some way a mentor to all four of these writers, and lived in Alexandria, the crossroad of the debate, during the decade it ensued. Just as Clark has noted that there must have been ample communication via letters among the disputants, it is nearly impossible to imagine that Didymus would have been uninformed, though nothing remains to attest to this.

16 De Viris Illustribus, hereafter Vir. Ill. For the critical edition, consult C.A. Bernoulli ed., Hieronymus und Gennadius: De Viris Inlustribus, Frankfurt, 1895 (Repr. 1968). The most recent English translation is from T. Halton, St. Jerome: On Illustrious Men, Fathers of the Church 100, Washington, 1999. The English translations of this paper are found in A Select Library of Nicene and Post-Nicene Fathers of the Christian Church, ed. by P. Schaff and H. Wace, 28 vols. in 2 series, Repr., Peabody, 1994. This series shall hereafter be abbreviated $N P N F$, followed by the series and volume number with the specific pages.

17 M.H. Williams, The Monk and the Book: Jerome and the Making of Christian Scholarship, Chicago, 2006, p. 158. Williams suggests that although Jerome's methods were perhaps less than historical, at least there is reason to concede that the titles contained in Vir. Ill. were actually read by Jerome. She also points out in her introduction that questions as to the historical reliability of Jerome's biographical notices are misplaced, "For the disagreements over whether particular elements of Jerome's scholarly method hold up to scrutiny have obscured what seem to me the most important issues. Whether they are for him or 
while very young and was ignorant of the basics of learning, yet "displayed such a miracle of intelligence as to learn perfectly dialectics and even geometry, sciences that especially require sight."18 Then Jerome lists several writings by Didymus, including the DSS that he translated and the commentary on Zechariah completed circa 388 at Jerome's request, and mentions that there are too many other works to give a full account of them in a limited space. He concludes that Didymus is still alive and over 83 years old. While there is not much information here, it is the first extant written statement that Didymus of Alexandria was not born physically blind and his condition did not prevent him from mastering the highest levels of education. Jerome mentions that Didymus' intellectual achievements were a witness to the grace of God - a miracle - not an attainment by Didymus' own effort. The mention of dialectics and geometry as the sciences requiring sight links Didymus to the philosophical tradition of Plato's Republic, where Socrates stipulates that dialectics is used at the highest stages of learning where the mind moves from knowing things through sense perception via geometry to an intellectual comprehension of reality constituted by the Forms, which constitute true knowledge. ${ }^{19}$ On the one hand, this brief reference suggests that Didymus is a Christian philosopher, occupying a place among the educated elite of late antique culture. But on the other hand, Jerome indicates that Didymus has progressed in knowledge to the highest degree, though his blindness would have made the transition through geometry and dialectic impossible since he lacked the physical sight that Plato prescribed as preliminary. Only by a miracle could this be explained. Thus, in the eyes of Jerome, Didymus' intellectual achievements give evidence that the blind author is favored by God's grace.

The next mention of Didymus' blindness is in Letter 68 to Castrutius, a blind man who wished to journey to the Holy Land to see Jerome, but was forced to return home. ${ }^{20}$ Jerome writes to console him and concludes with a story about Didymus, obviously because both were physically blind. ${ }^{21}$ Jerome reports that

against him, scholars of Jerome have tended to evaluate him in terms of modern canons of honesty, thoroughness and originality - standards that were unthinkable in Jerome's own day, which had its own norms for judging the scholarship that it produced." Instead, Jerome is better understood as a late antique person who is 'self-presenting' and 'selffashioning' himself as a scholar and ascetic; see pp. 18-22. That Jerome is self-presenting is obvious from the fact that he lists himself and his writings in the final notice of the illustrious men.

$18 \quad N P N F, 2 / 3$, p. 381; Halton, St. Jerome, p. 142-143.

19 Republic Book VII, 521-541.

$20 \quad C S E L 54$, pp. $677-678$; NPNF, 2/6, p. 141. The letter is dated 397 c.e.

21 Cain, Letters of Jerome, pp. 208-211. In Appendix One, Cain proposes a new taxonomy of Jerome's letters that would classify them according to the conventions of letter writing 
the events he describes to Castrutius occurred in his childhood, and relates an account of when Athanasius of Alexandria summoned blessed Anthony to the city to assist in defeat of the heretics, whereupon "Didymus, a man of great learning who had lost his eyes, came to visit the Hermit," and the two were discussing the Holy Scripture. ${ }^{22}$ This account reaffirms that Didymus was not born blind and it is the first written source linking Didymus to Athanasius and Anthony. But a few questions immediately arise. If we accept that Anthony visited Athanasius in Alexandria circa 337-338, than Didymus would have been in his mid to late twenties, assuming that we accept the dating of Didymus' birth to circa 310-313 c.e., and it is hard to imagine that Didymus would have garnered such a reputation for great learning so early in his career. ${ }^{23} \mathrm{Of}$ course, it is possible that Anthony made another trip to Alexandria during the period 346-356, the decade prior to Anthony's death, but then why is it not reported by Athanasius in Life of Anthony? Also, in 337, Jerome was not born yet, so how could the visit have occurred in his childhood? Perhaps Jerome heard this story second hand from others who had greater contact with Didymus so he is recounting poorly the hearsay biography of Didymus?24 Beyond these problems, the narrative may be an intentional construction or revision by Jerome, who shows Didymus as parallel to Castrutius, the blind man who wishes to visit a wise hermit, but in this case Jerome takes the role of Anthony. ${ }^{25}$ This would also be an intentional reversal of the historical reality of Jerome's visit to Didymus in Alexandria in 386 in order to consult about scripture. ${ }^{26}$ Here in the letter to Castrutius, Anthony, who was often praised as wise without having been formally educated, marvels at Didymus' insight and praises his abilities suggesting that Anthony esteemed learning and education, but then the hermit perceptively asks 'you do not regret the loss of your eyes, do you?'

common in late antiquity, such that this one to Castrutius is seen as exemplary of the category termed consolatory. Unfortunately, there is no further scholarship on this letter; cursory comparison with Jerome's letter to Abigaus (\#126), composed circa 399 c.e., reveals that Jerome does not preserve the lesson of Didymus' blindness, even though the circumstance that occasioned the later epistle to Abigaus is similar.

22 CSEL 54, p. 677; NPNF, 2/6, p. 141.

23 Layton, Didymus the Blind, pp. 20-21. Difficulty in establishing the date of Didymus' birth derives from the conflicting accounts of his age provided by Jerome and Palladius.

24 Williams, The Monk and the Book, pp. 268-269. There is debate about the date of Jerome's birth, but circa 347 c.e. is the most accepted.

25 Layton, Didymus the Blind, pp. 21-22.

26 This story is also intriguing in that it was composed during a brief truce in the debate over Origen, after the initial dispute between Jerome and Rufinus had abated and prior to the fury of Jerome incurred by Rufinus' Preface and Latin translation of Origen's Peri Archon in 399-400; in the exchange of Apologies by Jerome and Rufinus, the role of Didymus is paramount. 
Jerome relates that Anthony's query caused shame in Didymus, who refused to answer until prompted two more times, only then confessing that the physical blindness was a great grief to him. Anthony's reply is challenging to Didymus: "I am surprised that a wise man should grieve at the loss of a faculty which he shares with ants and flies and gnats, and not rejoice rather in having one of which only saints and apostles have been thought worthy."27 Jerome then drives home the point: "From this story you may perceive how much better it is to have spiritual than carnal vision and to possess eyes into which the mote of sin cannot fall." 28

Several elements of this narrative touch on Jerome's understanding of Didymus' blindness and his spiritual illumination. First, some scholars of Didymus have proposed that the legend linking Didymus to Anthony may actually derive from Didymus himself, since it is not recounted in literature about Anthony or Athanasius. ${ }^{29}$ If this is a tradition from Didymus himself, then it contains details that merit close scrutiny, as others have rightly noted. But caution is needed in taking the details of the tradition out of the context into which they have been inserted by each of Didymus' students, since Jerome, Rufinus and Palladius each rework the tradition to suit their own rhetorical goals. For example, in Jerome's letter to Castrutius, the characterization of Didymus is very complex. First, Didymus is portrayed in a rather humbling way, since Anthony's spiritual insight and questioning gets the best of the learned scholar Didymus, even silencing him with shame. Since Jerome wrote this in the midst of the Origen debate, it could be that he is subtly critiquing his esteemed teacher's stubbornness and failure to accept the wisdom of supposedly less learned monks like Epiphanius. But equally, if we accept the story as close to the tradition derived from Didymus, it suggests that a young, and perhaps distressed, Didymus was given valuable impetus by the wise Abba Anthony to pursue true spiritual vision. In this case, Jerome's characterization is complimenting Didymus, just as he had in the preface to $D S S$, as one who sought out the wisdom of the Spirit that is only granted to

$27 \quad C S E L 54$, pp. 677-678; NPNF, 2/6, p. 141.

$28 \quad C S E L 54$, p. $678 ; N P N F, 2 / 6$, p. 141.

29 Layton, Didymus the Blind, pp. 19-26. Layton asserts that the addition of Athanasius may derive from Rufinus' attempt to assert his own orthodoxy by lineage from Anthony and Athanasius through Didymus to himself, but this does not account for Jerome's usage unless the story came to Jerome by hearsay from Rufinus. Layton argues convincingly that the story is only known among Didymus' students, so it is likely derived from him (see pp. 22-23). Layton never discusses how the shifts in the details reflect divergence among Didymus' students about the nature of contemplative vision and the theological disputes revving up the Origenist crisis, for example, references to being like angels and translations of Origen's works such as the Homilies on the Song of Songs or on Leviticus. 
saints and apostolic witnesses. The account of Jerome proposes that Anthony prompted Didymus to seek the type of spiritual vision that other holy humans possess, namely saints and apostles, in contrast to the type of angelic vision Rufinus will propose that Didymus possessed. And just as he did in the preface to $D S s$, Jerome's allusion to eyes that resist the speck of sin in Luke 6:42 conjures up the rest of Jesus' parable (Luke 6:39-41), which raises the impossibility of a blind person guiding another blind person, and the assertion by Christ that 'no student is superior to the teacher; but when fully trained, every disciple will be like his teacher: 30 This passage speaks volumes given the complex interpersonal relationships between Jerome, Rufinus and their mutual teacher Didymus, not to mention the need to know oneself accurately before critiquing failures in a fellow student. Is Jerome suggesting that Didymus or Rufinus or both are blinded by Origen, or is he proposing that he is the true heir of Didymus, not Rufinus, since he has become like his teacher, guiding the blind Castrutius to spiritual vision? It is intriguing to ponder what Jerome might be suggesting based on his dispute with Rufinus over the heritage of Origen passed on to them both by Didymus. The story also hints that Didymus' own coping with his physical blindness required growth in spiritual maturity with the aid of a competent spiritual master. Finally, it demonstrates that in 397, Jerome still held Didymus in considerable esteem.

In Jerome's prefaces to his own commentaries and in the Apology related to the heated exchange with Rufinus in 399-402, Didymus is mentioned regularly, but after his letter to Castrutius, Didymus' blindness is rarely mentioned and praise of Didymus' spiritual insight diminishes. In fact, his writings reflect growing critique of Didymus, in particular the blind teacher's advocacy of a lenient acceptance of Origen, in spite of doctrinal errors that Didymus acknowledges to be present in Origen's works. ${ }^{31}$ At the beginning of Letter 84, Jerome relates that he had visited Didymus in Alexandria when he was already grey haired and he praises the blind master thus, "I have much to thank him for because what I did not know, I learned from him, and what I knew already, I did not forget, so excellent was his teaching." 32 We note the emphasis on the development of memory in connection to Didymus. Yet, he counters in Apology

\footnotetext{
$30 \quad$ Luke 6:39-40.

$31 \quad$ See Jerome's letter to Pammachius and Oceanus dated circa 400 c.e., CSEL 55, pp. 123-134; $N P N F, 2 / 6$, p. 180 and Apology to Rufinus, Book II, circa 402 c.e., CcsL 79 (Sanctus Hieronymous, Contra Rufinum, ed. P. Lardet, Turnhout, 1982); NPNF, 2/3, p. 507. While the critique of Didymus by Jerome coincides with the height of the controversy about the theology of Origen, it is also intriguing that Jerome waited until Didymus was deceased to openly doubt the orthodoxy of his former master. 
Book III, chapter 27, "As to Didymus, however, we extol both his powers of memory and the purity of his faith in the Trinity, while on the other point in which he erred in trusting to Origen we withdrew from him. The vices of our teachers are not to be imitated, their virtues are."33 In one of his final references to Didymus, circa 404, writing to Augustine of Hippo, (Letter 112), Jerome speaks of the authors he considered for his commentary on Galatians and states "I pass over my revered instructor Didymus." ${ }^{4}$ Jerome's admiration of Didymus did not diminish, even after the storms of debate with Rufinus, yet his assessment of Didymus' theology was not uncritical. Once the storms of controversy over Origen subsided, Jerome rarely mentioned Didymus; clearly he did not want to draw attention to his reliance on and admiration for a suspected heretic, though he does not deny the fact either.

\section{Didymus in the Writings of Rufinus of Aquileia}

The second disciple who mentions Didymus extensively is Rufinus of Aquileia, Jerome's one time friend, and the close collaborator of Melania in founding monasteries on the Mount of Olives. Like Jerome, Rufinus mentions Didymus frequently, but the material from him must be assessed carefully, since nearly everything he writes comes in response to information published by Jerome. This is especially the case with all mentions of Didymus in Rufinus' Apology to Jerome in two books, circa 400 c.e., where Rufinus gives actual quotations or summaries of the praises Jerome lavished upon Didymus in the prefaces to DSS and the scriptural commentaries, as well as some letters. But Rufinus is the one disciple of Didymus who spent a considerable number of years in his tutelage, if we accept his testimony that he "stayed in Alexandria where Didymus lived for six years and after an interval, for two more."35 Rufinus receives great attention among scholars because of his lengthy, detailed entry about the blind

$33 \operatorname{CCSL} 79 ; N P N F, 2 / 3$, p. 533.

34 CSEL 55, p. 371; NPNF, 1/1, p. 334. Jerome states "praetermitto Didymum videntem meum," which is challenging to translate directly into English; the context suggests that Jerome thinks of Didymus as possessing spiritual vision and as someone who had profound influence on his life.

CCSL 20 (Tyrannius Rufinus, Opera, ed. M. Simonetti, Turnhout, 1961) Simonetti also composed a critical edition of the Rufinus Apology against Jerome in Italian for Edizioni Paoline in 1957. For the English translation see NPNF, 2/3, Apology to Jerome, Book II, p. 466. Presumably, Rufinus stayed in Alexandria during the episcopacy of Peter II, circa $372-380$. Peter was driven from the patriarchal see briefly by the Arian Lucius in 373, and went to Rome where he gained the support of Pope Damasus, returning in the same year to Egypt. Though it is tempting to posit that Rufinus was always with Didymus during this 
teacher in his continuation of Eusebius' Ecclesiastical History, Book XI, chapter 7, but most especially because Rufinus says Didymus was the head of the Church school in Alexandria. ${ }^{36}$

As with Jerome's intertextual description of Didymus in the preface to Dss, so in Rufinus, we find Didymus' physical disability being transformed into a particular spiritual aptitude, but in this case with much greater detail than Jerome, perhaps because Rufinus has had more time to reflect on the contribution of Didymus. Although his account of Didymus is contained in Book 11, chapter 7 , the context is already established when he mentions in chapter 5 that relics of the Apostle Thomas Didymus are preserved in Edessa, and then again in chapter 6 when Rufinus describes the endurance of the Catholics in Alexandria "who shone with purer light" during the persecution caused by Lucius, the heretical bishop who attempted to succeed Athanasius. Near the conclusion of chapter 6, in recounting a debate between Lucius and the monk Moses, Rufinus poses this question: "Can that faith be truer which is perceived by the ears than that which is seen by the eyes?"37 All of these references are similar to things Jerome had indicated as the context for his characterization of Didymus.

Rufinus begins chapter 7 by reporting that when Alexandria was covered by the darkness of Lucius' heretical teaching, "The Lord lit Didymus to be like a lamp shining with divine light."38 The imagery is reminiscent of Jerome's mention of the virgins' lamps, but Rufinus may also be comparing Didymus to the famous Pharos lighthouse that graced Alexandria's harbor, since he claims that Didymus was "given by God for the glory of the Church."39 Next, Rufinus provides a detailed description of Didymus that rivals Jerome. Just as before, we learn that Didymus was not born blind, but became so as a young child before learning his letters. Rufinus tells us that the onset of blindness did not cause despair, in contrast to Jerome's hints of this in his account of Anthony's visit in the letter to Castrutius, but instead Didymus was motivated to desire knowledge of the True Light. Rufinus notes that Didymus put his trust in the

time, it may not be true, since Rufinus mentions learning from several teachers in Alexandria.

36 The Church History of Rufinus of Aquileia: Books 10 and 11, tr. by P. Amidon, Oxford, 1997, pp. 69-70. Amidon discusses the issues of critical editing and the historical reliability of Rufinus' work in his introduction, pp. xiii-xvii. Since our interest for this paper is not in Didymus' role as an authorized teacher, but the accounts of his blindness, we have not given Rufinus undue importance, and treat the data in chronological order as composed and published.

37 Church History of Rufinus, pp. 67-68.

38 Church History of Rufinus, p. 69.

39 Church History of Rufinus, p. 69. 
gospel promise that all things are possible to God and so prayed unceasingly, not for physical sight but for an illuminated heart. In this section, Rufinus is using intertextual biblical references to describe Didymus in a way consistent with Didymus' own practice, just as Jerome had done. For example, the quote that what is impossible for humans is possible for God conjures up several scriptural verses: Jesus' parable about the camel passing through the eye of the needle, ${ }^{40}$ the angel Gabriel's words to Mary at the Annunciation, ${ }^{41}$ and the faith needed for God's mighty deeds when Jesus heals the mute and deaf boy. ${ }^{42}$ Similarly, Rufinus' characterization of Didymus' attitude and unceasing prayer echoes what Paul advocates in 1st Thessalonians 5:17-18, and Ephesians 1:16-18, where the Apostle prays that his followers would be given wisdom and knowledge of God through the enlightenment of the eyes of their hearts that produce hope.

Rufinus adds to this spiritual portrait several material details that describe how Didymus acted upon the grace of God. First, Rufinus says Didymus dedicated himself to "work and study combined with prayer, and had recourse to continuous and uninterrupted hours of wakefulness not for reading but for listening." ${ }^{33}$ It seems that while other people were distracted by carrying out the necessities of practical daily life, Didymus devoted these hours to listening rather than reading, such that he learned by memorizing what he heard and unlike others who attempted to learn by writing things down. Rufinus tells us that Didymus had a crew of readers who recited the text for him after dark, but when they fell asleep, the blind master would continue to work by holding vigils in the silence of night to ruminate on what he heard. ${ }^{44}$ Rufinus says that by doing this, Didymus was behaving like a clean animal chewing its cud, a reference to Leviticus 11:3, and likely Rufinus is drawing upon Origen's Homily 7 on Leviticus that suggests a spiritual interpretation of the verse such that it refers to a person who pays heed and listens to knowledge, and meditates day and night, and after chewing up the letter of the scripture, moves on to the spiritual sense, ascending from visible things to invisible things, and becomes able to discern what deeds pertain to the present life, and which pertain to the

\footnotetext{
$40 \quad$ See Mark 10:23-27, Matthew 19:23-27, and Luke 18:25-27.

$41 \quad$ See Luke 1:37.

42 See Mark 9:17-29 and Matthew 17:20.

43 Church History of Rufinus, p. 69.

44 We might like to presume that Rufinus was aware of the vigils of Didymus because he lived with him as a disciple, perhaps even as a reader, but he never claims to be an eyewitness to this practice, and the resumption of the scriptural allusions (i.e. Jesus' vigil in Gethsemane where the disciples nod off and the animal chewing it's cud from Leviticus 11:3) casts some doubt on the historical reliability of the account.
} 
future age to come by using proper reason so as not to be a confused camel. ${ }^{45}$ Just as with Jerome, it is Didymus' memory that Rufinus highlights, saying that instead of rewriting what he heard on physical pages of papyrus, he slowly inscribed what he learned on the pages of his own mind. In this way, Rufinus shows that Didymus overcame the difficulties of writing and memory highlighted by Plato in the Phaedrus 274c-277a, so that Didymus makes both philosophical and scriptural wisdom alive within himself. ${ }^{46}$ And just like Jerome, Didymus is characterized as a type of Christian philosopher, who can ably respond to any query and can easily best other philosophers in debate. ${ }^{47}$ Rufinus even reports that Didymus' erudition was recorded and preserved by stenographers and his ideas are 'still' esteemed, suggesting that by 402 c.e. Didymus had died.

Rufinus wraps up his treatment of Didymus by saying that, as a disciple of Didymus, both in person and through his writings, he and others perceived something divine in his words, a characteristic applied by Gregory Thaumaturgus to Origen in his panegyric to his teacher. ${ }^{48}$ But Rufinus' final anecdote tells of Anthony meeting Didymus while on his way to Alexandria to defeat the Arians in aid to Athanasius. As mentioned above in note 29, Rufinus uses this story to solidify his own orthodoxy through association with the father of monks and father of the Nicene definition. However, unlike Jerome's letter to Castrutius, in Rufinus' version Anthony and Didymus do not discuss scripture and Didymus is not silenced in shame by the hermit's query about his loss of physical sight. Rather, Anthony consoles him saying "what you lack are those eyes which mice, flies and lizards have," all of these being the unclean animals described in Leviticus 11:20-29, and Didymus should "rejoice that you have the eyes which angels have, by which God is seen, and through which a great light of knowledge is being lit for you." ${ }^{49}$ In this reference, Rufinus is also recalling

45 Origen's Homilies on Leviticus 1-16, tr. by G.W. Barkley, Fathers of the Church, vol. 183, Washington DC, 2005, pp. 148-149. Rufinus assertion that Didymus presided over a catchetical school in Alexandria is likely an attempt to raise Didymus to a status similar to Origen, just as is his reference to Didymus' divine manner of speech. This is not to say such a school did not exist, but its nature as an institution officially sanctioned by the church remains much debated.

46 That Rufinus has Phaedrus in mind is evident from the fact that he mentions astronomy and arithmetic in addition to dialectics and geometry, as Jerome had done in his Vir. Ill., 109.

47 Church History of Rufinus, p. 69.

48 Layton, Didymus the Blind, pp. 13-14.

49 Church History of Rufinus, p. 70. The animals referred to (mice, flies and lizards) are different than those in Jerome's account. Layton says that Jerome makes a similar reference in his Letter 76 to Abigaus, a blind presbyter in Spain, where he refers to the ants, flies and 
Ezekiel 10:12 where the eyes of the angels are described and he may be positing one of the points debated in Origen's theology that in the resurrection the saints shall have bodies like angels. ${ }^{50}$ As was the case with Jerome, the writings of Rufinus yield some significant biographical detail about Didymus' exalted reputation, education, spirituality, and pedagogical procedures, including the use of lectors and scribes. But, when examined carefully, they reveal just as much about the theological significance of Didymus for Rufinus.

\section{Didymus in the writings of Evagrius of Pontus}

The next contemporary source about Didymus derives from another monastic visitor, Evagrius of Pontus, who like Jerome probably had only a brief encounter with the blind master, but greater acquaintance with his method and reputation by way of his monastic friends Melania and Rufinus. Evagrius had originally been a disciple of Basil of Ceasarea but came to Constantinople and assisted Gregory of Nazianzus during the Ecumenical Council of 381. Thus, Evagrius was in Constantinople at the same time as Jerome, though there is no evidence

creeping things and that Jerome has appropriated the anecdote about Didymus and Anthony to another circumstance. Layton favors the reliability of Rufinus, and suspects Jerome of rhetorically altering the tradition to suit his needs. This misses the significance of the small change in the list of animals given in each source. Jerome's Letter 68 lists "ants, flies and gnats" referring to Exodus 8:12-25, Leviticus 11:20-23 and Psalm 105:31 because these are all unclean animals that should not be eaten and are a plague upon God's people, whereas Jerome's Letter 76 lists ants, flies and lizards derived from Proverbs 30:24-28 where they are considered the wisest of animals. In Letter 68 Jerome is making a point about Didymus being humbled by Anthony, whereas Letter 76 encourages Abigaus to be wise like those wise animals. Rufinus' use of the anecdote is to counter the critiques of Didymus by Jerome during their debate over the use of Origen, and so he lists mice, flies and lizards from Leviticus 11:20-29 as unclean animals whom Didymus does not imitate. Although there may be a tradition of Didymus meeting Anthony that predates their writings, both Jerome and Rufinus are situating it to suit their own rhetorical purposes. Layton's judgment that Jerome has not preserved the earliest form of the anecdote ignores the fact that all of Rufinus' writings are written after Jerome has begun to sully the name of his former teacher Didymus, and as such, they are just as likely to be rhetorically biased. Additionally, what unites Jerome and Rufinus is their use of Origen: this is why Jerome claims Didymus has the eye of the bride and Rufinus says he is a clean animal that chews the cud. Since both Jerome and Rufinus contain the anecdote but apply it to Didymus according to their own reading of Origen, the historical reliability of both must remain suspect. While it is likely that Didymus was the source of the tradition about Anthony and Athanasius, the version of Rufinus is no more historically reliable than that of Jerome, contrary to the claim of Layton, Didymus the Blind, 2004, pp. 21-23.

See Jerome's Letter 84, CSEL 55, pp. 132-134; NPNF, 2/6, p. 178. 
that they met, and like Jerome, Evagrius departed the city soon after the resignation of Gregory. While Jerome proceeded to Rome, Evagrius traveled to Palestine and met Melania and Rufinus, who prompted him to pilgrimage to Egypt to strengthen his monastic vocation. At their behest, he stopped in Alexandria to meet Didymus, but did not stay long, since Evagrius soon moved on to the monasteries in Nitria and Kellia, where he lived until his death in 399.51

Evagrius only mentions Didymus once in his extant works, but in a significant place, at the conclusion of the Gnostikos, the second book of his three volume work on the monastic life. ${ }^{52}$ The brief chapter dedicated to Didymus is near the conclusion of the fifty kephalia and the last in a series of chapters which acclaim teachers Evagrius considered important, three being masters he himself knew; the five, in order, were Gregory of Nazianzus, Basil of Caesarea, Athanasius of Alexandria, Serapion of Thmuis and finally Didymus. ${ }^{53}$ In his notice for Didymus, there is no explicit mention of blindness nor any biographical data, only enigmatic allusions to Didymus' qualifications as a gnostikos. Indeed, each of the five masters is portrayed as a model for the aspiring spiritual guide, and among them, Didymus, the last listed, is called "the great knower and teacher". ${ }^{54}$ Scholars of Evagrius point out that the Gnostikos was a list of 50 chapters intended by Evagrius to be used by an accomplished ascetic who was capable to act as a spiritual guide to other dedicated ascetics. This gnostikos "was to adopt a particular monastic system of education gleaned from classical philosophy adapted to Christian teaching." ${ }^{55}$ By placing him last, Evagrius is stipulating that Didymus is one of the best at spiritual guidance and the use of scripture. This implies that Evagrius is familiar Didymus' actual

$5^{1} \quad$ The role of Evagrius in the debate about Origen has been greatly studied and retrieved in recent decades, such that it is now understood that he was central to the theological issues involved. Unfortunately, the role of Didymus in the dispute has not been adequately addressed, and perhaps can not be, due to lack of correspondance that would make known his theological position vis-á-vis the other disputants.

It is difficult to ascertain the exact date when Evagrius composed and published the Gnostikos; since the date is unknown, we have assumed it was composed after Evagrius arrived in Egypt in 383, and prior to his death, circa 399; publication may not have occurred until after his death. Because of this difficulty, and the brevity of his notice, we have placed our consideration of Didymus in the writings of Evagrius of Pontus after that of Rufinus, though it was likely composed prior to the publication of anything about Didymus from Rufinus, and certainly prior to Palladius, who was Evagrius' disciple.

53 Intriguingly, the first four of these are bishops, but Didymus is a greater teacher than they.

54 CPG 2431. For the Greek and English of the Gnostikos, see the website of L. Dysinger: $<$ http://www.ldysinger.com/Evagrius/o2_Gno-Keph/ooa_start.htm>.

55 R. Darling Young, "Evagrius the Iconographer," Journal of Early Christian Studies, 9:1, 2001, p. 53 . 
practice of spiritual direction, either through personal experience, or through hearsay from others like Melania and Rufinus. Evagrius' painting of Didymus as a gnostikos also coincides with the portrait of Didymus presented by Jerome and Rufinus.

Experts on Evagrius further say that "the gnostikos' principal textbook is the bible ... exegesis consists in the search for biblical texts that will benefit spiritual counsel." ${ }^{\text {6 }}$ Since the spiritual director is expected to 'give a word' corresponding to the degree of progress of the ascetic disciple, a large stockpile of memorized biblical texts is necessary, as is deep familiarity with how to wisely apply the various levels of spiritual meaning in the bible. ${ }^{57}$ The gnostikos was expected to be someone who knew both the course of salvation history at the macro level of the bible and creation, as well as the particulars of each soul's odyssey on the micro level. ${ }^{58}$ Evagrius' characterizes Didymus as teaching the following:

Exercise yourself continuously in the logoi of providence and judgment and strive to bear in your memory their material (expression): for nearly all are brought to stumbling through this. And you will discover the logoi of judgment in the diversity of bodies and worlds, and those (logoi) of providence in the means by which we return from vice and ignorance to virtue and knowledge. ${ }^{59}$

That Evagrius posits Didymus as the great gnostikos and teacher who encourages the development of memory on the part of the would be gnostikos fills out our understanding of how Didymus was understood by his students he was more than an expert exegete or astute theologian, he was an accomplished spiritual master, a guide who could lead disciples through the darkest aspects of the interior journey. And it was his particular physical circumstance that contributed greatly to the development of this expertise. For Evagrius, just as for Jerome and Rufinus, Didymus is especially endowed

56 L. Dysinger, "Evagrius Ponticus: Exegete of the Soul," in Evagrius and His Legacy, ed. by J. Kalvesmaki and R. Darling Young, Notre Dame IN, 2016, pp. 76-77.

57 Dysinger, "Evagrius Ponticus," pp. 76-77 and 89.

58 Dysinger, "Evagrius Ponticus," p. 74.

$59 \quad C P G$ 2431. See Dysinger's website for the English translation of chapter 48 of the Gnostikos. For a full discussion of the importance of the logoi of Providence and Judgment in the theology of Evagrius, see Dysinger, "Evagrius Ponticus," 2016, pp. 84-89. Clearly, Evagrius is suggesting that Didymus is firmly within the spiritual and intellectual milieu of Origen with the use of such technical terminology. Whether Didymus taught such things would require further research to determine, but it is clear that Evagrius characterizes him as a part of this tradition. 
with spiritual vision; his physical blindness, though never mentioned, is intimately and implicitly linked to the development of his spiritual insight. ${ }^{60}$

\section{Didymus in the writings of Palladius of Galatia}

The last eyewitness account of Didymus comes from the Lausiac History composed in 419-420 c.e. by Palladius of Galatia, who like the other three eyewitnesses had sojourned in Egypt at the conclusion of the fourth century. ${ }^{61}$ Though he was approximately 20 years younger than Jerome, Rufinus and Evagrius, like them he became a monk and lived in Nitria and Kellia, where he was a disciple of Evagrius. His account of Didymus appears in chapter four of his History and contains similar information to the others, but his description is much different, completely lacking the type of intertextual layering of biblical verses found in Jerome and Rufinus that was reminiscent of Didymus' own exegetical procedure. Instead, Palladius simply says that Didymus was a blind author in Alexandria whom he met four times over the course of the last decade of the fourth century. From his notice, it is clear he was in Egypt at the time of Didymus' death, since he states succinctly that the teacher died at the age of 85 . Unlike the others, Palladius states that his information about Didymus was gained from the mouth of Didymus himself, but like the other witnesses, he reports that Didymus lost his eyesight at the age of four and never learned to read or attended school. According to Palladius, Didymus did not need formal education, instead being taught by his own conscience. ${ }^{62}$

6o Even though there is no explicit statement in Evagrius' notice of Didymus' blindness, he

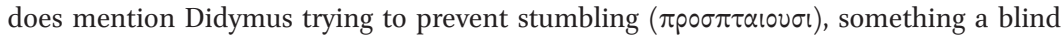
man would be quite familiar with and want to prevent, and where to discover or find

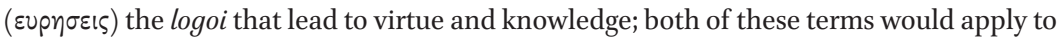
a blind person seeking a way forward, and it would be in keeping with Evagrius' style to make such a veiled reference to Didymus' physical condition.

61 Palladius, The Lausiac History, trans. by R.T. Meyer (Ancient Christian Writers 34), Mahwah, 1964, pp. 35-36. The critical edition of Palladius' History remains the two volume work done by Dom Cuthbert Butler in 1898 and 1904, reprinted recently by Cambridge University Press, 2014. Butler's first volume provides consideration of the various rescensions and translations of The Lausiac History from original Greek into Latin, Syriac, Armenian, Coptic and Ethiopic, as well as consideration of its historical reliability and the context of Egyptian monasticism that frames it. In volume two, Butler provides the Greek text with critical apparatus. Recently, significantly updated scholarship has been provided by D. Katos, Palladius of Helenopolis: The Origenist Advocate, Oxford, 2011. Clark, Origenist Controversy, also details the role of Palladius in the debate, see pp. 21-25, 44-50, 188-191.

62 Palladius, Lausiac History, p. 35 . 
Similar to Jerome, Palladius says that Didymus received the gift of knowledge so that in him Psalm 146:8 was fulfilled: "the Lord makes the blind wise;" through this gift, Didymus was able to interpret the bible and explain doctrine more effectively than the ancients. ${ }^{63}$

Palladius concludes his characterization of Didymus with three anecdotes told to him by the blind teacher, one about Anthony praying when he visited Didymus, a second that suggests Didymus had a vision of the Emperor Julian's death that was reported to Athanasius, and a third that relates the story of the anchoress Alexandra, who locked herself inside a tomb so as not to be seen but was visited by Melania the Elder. These stories have very little similarity to those of Jerome and Rufinus, except that one refers to Anthony visiting Didymus and another that Didymus reported his ecstatic vision to Athanasius. In these two cases, Didymus is clearly the focal point of attention, though in the third, he is only the one who relates the story.

In the Lausiac History, the anecdote about Anthony's visit is recounted in such a way that it completely reverses Jerome's account in Letter 68 to Castrutius and also differs markedly from the account in Rufinus' Church History. Anthony comes to visit Didymus on a third occasion and is willing to obediently humble himself when the blind master instructs the hermit to kneel and pray ${ }^{64}$ Unlike the accounts of Jerome and Rufinus, there is no indication that Anthony spoke challenging or consoling words to Didymus regarding his physical blindness. In contrast to Jerome's letter, Anthony comes to visit Didymus in the blind teacher's cell rather than Didymus going to visit Anthony; also, Anthony is the one humbled at the request of Didymus, rather than Didymus being shamed by the words of Anthony. Palladius offers the anecdote as an example of how Didymus challenged and corrected him for being unwilling to obey the teacher's request to pray, even though he was seeking to imitate the virtuous life of the hermit Anthony. ${ }^{65}$ In Letter 68 of Jerome, Anthony came to Alexandria in answer to a summons from Athanasius to argue against unspecified heretics, whereas Rufinus said Anthony came to Alexandria specifically to oppose the Arians with the faith of Athanasius but never suggests that the hermit was summoned by the bishop. Palladius' account implies that Anthony the hermit was intentionally coming to see Didymus, and Didymus' words to Palladius are an exhortation for him to curb his irascibility.

\footnotetext{
63 Palladius, Lausiac History, p. 35.

64 Palladius, Lausiac History, p. 35. That this anecdote recounts a third visit of Anthony to Didymus in Alexandria could be the result of Palladius' attempt to make sense of the two different traditions in Jerome and Rufinus, and to lend credence to his own story.

65 Palladius, Lausiac History, p. 35-36.
} 
The second anecdote in the History of Palladius describes how Didymus was so disturbed by the persecutions of Julian the Apostate that one day he neglected to eat his bread and sat awake until late in the evening when he dozed. During his sleep he had a vision of messengers on white horses coming with news of Julian's death that he was instructed to pass along to Athanasius; and marking the time of the vision, it was confirmed to be accurate. ${ }^{66}$ This story makes the link between Didymus and Athanasius, but completely removes the mediation of Anthony present in Jerome and Rufinus, indicating that Didymus and Athanasius already had established communication from previous interactions, perhaps Anthony's two other visits implied by Palladius. Furthermore, the date indicated suggests that the blind teacher and exiled bishop were in communication during the first half of 363 , since Julian died on 26 June, 363; this is the period when On the Holy Spirit and several other of Didymus' writing were composed. ${ }^{67}$

Although neither of the first two anecdotes makes issue of Didymus' blindness, the third anecdote suggests that vision was on the mind of Didymus when he spoke to Palladius. This anecdote is actually considered part of chapter five of the Lausiac History, but Palladius clearly states that he heard about the anchoress Alexandra from Didymus. ${ }^{68}$ Indeed, the anecdote about Alexandra has two parts, the first related by Didymus and the second originating from Melania the Elder, who was in the monastic environs of Alexandria following the death of her husband circa 371 until Athanasius died in May of 373. Thus, the events of this story would date from a period ranging from the early 360 's to the early 380 's, since Melania spoke to Alexandra during her visit, and Didymus claims she was an anchoress for ten years prior to her death, during which time she saw no woman or man face to face. ${ }^{69}$ In this case, Alexandra is similar to Didymus, who does not see other human faces. Didymus also relates that when a woman who regularly visited her got no answer, he and others went and broke down the door and found Alexandra dead..$^{70}$ The most intriguing element of this story is that its joint storytellers,

$66 \quad$ Palladius, Lausiac History, p. 36.

67 This date is important because it establishes a connection between Didymus and Athanasius at the very time that they were both responding independently to heretical ideas that denied the divinity of the Holy Spirit and marks the outset of Didymus' publishing career. See Works on the Spirit, ed. by M. DelCogliano, A. Radde-Gallwitz and L. Ayers, pp. 35-48 and Layton who dates the composition of several of Didymus' published commentaries to this period: R. Layton, Didymus the Blind and His Circle, pp. 6-7.

68 Palladius, Lausiac History, p. 36.

69 Assuming Didymus' birth is dated to 310-313 c.e., he would be in his fifties or sixties at the time these anecdotes occur, a period that was the height of his publishing career. Palladius, Lausiac History, p. 36. 
Didymus and Melania, were both important influences on Palladius and Evagrius, his spiritual master, as well as Jerome and Rufinus. Palladius is making a parallel between Didymus and Alexandra also, since he introduces them at the beginning of his notice on Didymus by saying that the Alexandrian Church perfected many saintly women and men to be "worthy to inherit the land of the meek" referred to in Matthew 5:5. ${ }^{71}$ But, unlike Jerome and Rufinus, Palladius scriptural allusion is very muted, and much closer to the practice of Evagrius, where only a few words were expected to call to mind a host of scriptural passages.

The notice in the Lausiac History generally lacks intertextual exegesis and any explicit reference to Didymus' memory, other than the three anecdotes he recollects about Anthony, Athanasius and Alexandra. But Palladius does draw upon the notions present in Jerome that Didymus was an exceptionally wise intellectual and spiritual seer who received visions of portentous events, similarly, he is portrayed as one who is astute concerning spiritual direction for aspiring monastic novices, as is portrayed in Evagrius' Gnostikos, and following Rufinus, Didymus is characterized by communion with the heros of orthodox monasticism in Egypt. The firsthand reminiscenses, though not intertextually related to scripture, do showcase Didymus' powers of memory. And perhaps most telling is the one new element in Palladius' portrait of Didymus, namely that it is best for monastics to lay aside all contentiousness; clearly this would have been true wisdom for anyone connected with the controversies that embroiled Jerome, Rufinus, Evagrius and Palladius, since he became the ardent supporter of Chrysostom. Perhaps what Palladius recalls of Didymus' wisdom came only after he tasted the bitterness of intra-ecclesial disputes.

Through this comparison of the earliest references to Didymus in the writings of Jerome, Rufinus, Evagrius and Palladius, it becomes evident that the lack of physical vision was a locus for theological reflection, spiritual inspiration and rhetorical persuasion, such that what might be considered an impediment to human development became a stimulus to spiritual well-being and health. In the view of his disciples, Didymus was not cursed with blindness, but blessed

$71 \quad$ Palladius quotes Matthew 5:5 because the entire anecdote is to be understood in light of Jesus' Sermon on the Mount, since the chapter also contains reference to Alexandra's purity in not wanting to lead another into lust or discouragement so as to maintain peace, her only eating enough to survive so that she hungers more for righteousness and, like Didymus, will eventually see God face to face. 
with a gift that enabled him to develop an unique talent incomparable to his contemporaries, a mind inscribed by memory in such a way as to intimately know the Word of God without the aid of a physical text. It is also evident that the personal encounter with Didymus was memorable, and his pedagogical praxis had particular appeal to monastics who sought to mimic him in written documents in order to encourage a similar development of mental inscription in their companions and disciples. Sadly, what this paper also illustrates is that reliable biographical data about Didymus remains elusive and vague, and insight into his own self-understanding of his physical blindness may be difficult to retrieve, since he rarely inserts his personal experience into his own exegesis of biblical texts. Hopefully, this study has opened some new pathways to consider physical disability as an asset for those who are interested in spiritual health. 